Canadian University Music Review

Revue de musique des universités canadiennes

\title{
Learning the Koto
}

\section{Patrick Halliwell}

\author{
Numéro 14, 1994 \\ URI : https://id.erudit.org/iderudit/1014309ar \\ DOI : https://doi.org/10.7202/1014309ar
}

Aller au sommaire du numéro

\section{Éditeur(s)}

Canadian University Music Society / Société de musique des universités canadiennes

\section{ISSN}

0710-0353 (imprimé)

2291-2436 (numérique)

Découvrir la revue

\section{Citer cet article}

Halliwell, P. (1994). Learning the Koto. Canadian University Music Review / Revue de musique des universités canadiennes, (14), 18-48.

https://doi.org/10.7202/1014309ar

\section{Résumé de l'article}

This paper examines traditionally-oriented teaching and learning processes in Japanese koto music. Earlier evaluations (negative and positive) by Western scholars are introduced, together with a brief comparison to Western practices. A distinction is made between "inside" and "outside" students; the former have greater exposure to music and speech about music, and teaching methods also may differ. Traditional methods of learning through imitation are shown to have other musical goals besides the transmission of musical "text." Playing together is fundamental; teachers may use speech, shôga (oral representation of instrumental sound), or purely musical means to convey information to the student. Notation, often used nowadays, is nevertheless of relatively minor importance. The dominant values underlying traditional teaching methods are expressed through the phrase "if you can steal it, that's OK." Finally, concepts of "text" and "interpretation" are considered in relation to values concerning change in traditional koto music.
All Rights Reserved @ Canadian University Music Society / Société de musique des universités canadiennes, 1994
Ce document est protégé par la loi sur le droit d'auteur. L'utilisation des services d'Érudit (y compris la reproduction) est assujettie à sa politique d'utilisation que vous pouvez consulter en ligne.

https://apropos.erudit.org/fr/usagers/politique-dutilisation/ 


\section{LEARNING THE KOTO'}

\section{Patrick Halliwell}

\section{Introduction}

Although participation in music-making is now commonplace in ethnomusicology, learning processes themselves have seldom been given close attention. Yet it is essential, at some point, to consider how people learn and teach music. After all, musicians do not approach music on the basis of hypothetically "universal" laws of psychology or aesthetics, but on the basis of their own experience. An important part of this experience consists of some kind of process of learning, whether this is formalized and systematized or not. Environment and training have a significant influence on how people perceive, think about, talk about, and do music. For an ethnomusicology which rightly regards music as culture, investigation of learning is fundamental; as Alan Merriam noted long ago, "the learning process in music is at the core of our understanding of the sounds men produce." 2

This paper addresses certain aspects of teaching and learning in traditional koto music. As with other genres of Japanese music, teaching methods and the circumstances of koto instruction have changed as society has changed. For example, lessons to most students are now given only once weekly, rather than almost every day as they once were. This has been accompanied by the increased use of scores and commercial recordings; cassette tapes are also commonly used by students to record lessons. Such change has not been uniform or always according to consensus; indeed, there are ongoing debates about teaching methods, the relationship of student and teacher, the development of formalized "theory," and other issues, as can be seen in the pages of trade magazines such

1 I am especially grateful to my koto teachers, Fujii Kunie and Fujii Hirokazu, for many hours of discussion on these and other matters. I am also thankful to other musicians who contributed to my research in various ways, as well as to Gerald Groemer for helpful comments and advice on this paper. Research and study in Japan (1987-91) was funded by the Japanese Ministry of Education (Monbushô); this paper was written under a Doctoral Fellowship (1991-93) from the Social Sciences and Humanities Research Council of Canada. All interviews were conducted in Japanese; in translation I have tried to maintain the idiomatic flavour of the original spoken Japanese. For a glossary of principal Japanese terms, see the Appendix to this article.

2 Alan Merriam, The Anthropology of Music (Northwestern University Press, 1964), 163. 
as Kikan Hôgaku ("Japanese Music Quarterly") and Hôgaku Jaanaru ("Japanese Music Journal"). Most of the older professional koto musicians active today, however, learned in ways that may be described as more-or-less traditional; a number of younger musicians, especially those born into or raised in musical families, have also been trained in more traditional ways. In observing modern practice, of course, it is sometimes difficult to separate the "traditional" from that which is not. Nevertheless, without trying to reconstruct some kind of romantic ideal, and without entering into the ongoing debates on the merits of various teaching methods, we may consider the ways that some of these musicians have learned and taught music, and the ways that they teach today. These are essential to an understanding of the musician's perspective.

Since the focus here is on what actually happens in lessons, issues related to the social control of music-making, as well as the social systems that enforce such control, will not be dealt with directly. It must be noted, however, that the koto world is divided into social units referred to as ryûha ("schools and subschools"); these are organized hierarchically, generally under the control of an iemoto ("head of the household/school"), and the whole is often referred to as the "iemoto system" (iemoto-seido). Students must learn the repertoire and playing style of their particular social unit. Even when qualified as a performer and teacher one remains subordinate to one's own teacher and iemoto. To many, both insiders and outsiders, this social background is responsible for some of the most negative aspects of the world of traditional Japanese music. Not a few musicians chafe under the social and musical restrictions and obligations imposed upon them, and it is not uncommon for someone to leave music entirely, for unless one is already established at a high level, exceptionally talented, and possessed of an uncommonly strong personality, one cannot be active in traditional music without the approval of one's teacher. Those who benefit most directly from established ways, of course, are likely to disagree; as one person candidly told me, "Of course I think the iemoto system is a good thing. It's expensive to live here in Japan. How else could I afford a house like this?" In any case, it must be recognized that the strong social background to traditional music has played an important role in its survival in the face of social change. For present purposes, it is sufficient to note that social aspects, including that of control, are in some cases intimately related to certain aspects of traditional teaching/learning processes; for this reason, changes in attitudes, values and methods in teaching/learning may also be closely linked to social change. ${ }^{3}$

3 Introductory discussions in English of some aspects of the social systems underlying performance and transmission can be found in, for example: Andreas Gutzwiller, "Shakuhachi: Aspects of History, Practice and Teaching" (Ph.D. diss., Wesleyan University, 1974), 147-67; Catherine Read and David Locke, “An Analysis of the Yamada-ryu Sokyoku Iemoto System," Hogaku 1/1 
As Seeger has argued, musicology takes place in a metaphoric juncture, where the intersecting elements include musicologists and their audience. ${ }^{4}$ It is for this reason - not because Western methods are thought to be any kind of yardstick for measurement - that I wish to begin by looking at some Western evaluations of traditional teaching methods in Japanese music. These show two extremes; rejection of Japanese methods because they are quite different from those used in mainstream Western classical music, or acceptance of such methods simply because they are the "Japanese way." It will be seen that both of these viewpoints suffer from inadequate consideration of what actually goes on in Japanese music lessons. Also, it may be noted that what actually happens in Western music does not always correspond to what musicologists construe that tradition to be. Therefore, it is hoped that the following discussion will stimulate readers familiar with the Western or other traditions to re-evaluate them in the light of their own experience.

\section{Western Evaluations of Japanese Music Teaching}

\section{Comparison with Western Methods}

Scholars brought up in the Western classical tradition have sometimes looked unfavourably on traditional teaching methods in Japanese music. A century ago, Francis Piggott wrote about teaching and learning the koto:

... the training is far from perfect: there is no general grounding in intervals such as the Western pupil must go through ... ${ }^{5}$

'Ten hours a day for ten years' is the initial routine of drudgery ... it brings the students to the threshold of their professions, furnished with an accuracy which is never afterwards shaken off: it has become their second nature. It has, indeed, done more: except in the case of genius of a high order it hás

(1983): 20-52. More substantial critical investigation is needed. Japanese musicologists sometimes hint at the negative aspects of these systems: e.g., Hoshi Akira, Nihon-ongaku no rekishi to kanshô (Tokyo: Ongaku no tomo-sha, 1971), 94-95; Motegi Kiyoko, "Aural Learning in Gidayû-bushi: Music of the Japanese Puppet Theatre," Yearbook for Traditional Music 16 (1984): 97-108; Tokumaru Yosihiko, "The Interaction of Orality and Literacy in Structuring Syamisen Music," in Tokumaru Yosihiko and Yamaguti Osamu, eds., The Oral and Literate in Music (Tokyo: Academia Music, 1986): 110-29. However, it generally seems to be hoped that these matters will be attacked some day by an "outsider" who has nothing to lose.

4 Charles Seeger, "The Musicological Juncture: 1976," Ethnomusicology 21/2 (1977): 179-88.

5 Francis Piggott, The Music and Musical Instruments of Japan (London: B.T. Batsford, 1893), 63. 
crushed the first nature with its abundant gifts out of existence; ninety out of every hundred artists and musicians, when the years of study have run their course, have become the merest mechanics. Means to achieve the required end are unknown; the end itself is studied, and is achieved by continued repetitions. In music, scales and exercises, studies, and all the paraphernalia with which the pupil is armed in the West, do not exist. ${ }^{6}$

William Malm, writing more than thirty years ago, echoed such sentiments:

[regarding koto teaching]

There are some students who do not read readily the notation and learn the entire piece by imitating the teacher. ${ }^{7}$

... the teaching method is uninspired by Western standards ... ${ }^{8}$

As a teaching method, hogaku [Japanese traditional music] instruction seems unnecessarily tedious. The rote method, as used in Japan, is constantly in danger of producing musical automatons. ${ }^{9}$

[regarding teaching of Giday $\hat{u}$-bushi]

... this slow, mechanical process is typical of Japanese teaching methods. It does have the advantage that the resultant performances are practically automatic conditioned responses. ${ }^{10}$

If one were to generalize, for comparative purposes, about the teaching of instrumental performance and singing in Western classical music, it could be said that there are four major components. These include: (1) the transmission of musical "texts," which are usually regarded as being more-or-less fixed in notation; (2) the transmission of formalized and systematized "theoretical" knowledge, mainly concerning the underlying musical system; (3) the transmission of knowledge about the technical/physical aspects of sound production (often involving the use of "exercises," which are conceptually distinguished from musical "works"); and (4) the transmission of knowledge about the "interpretation" of musical texts, as distinct from the texts themselves.

Western classical music is often characterized as a written tradition. This is

6 Ibid., 64.

7 William Malm, Japanese Music and Musical Instruments (Tokyo: Charles E. Tuttle, 1959), 171.

8 Ibid., 172.

9 Ibid., 172.

10 Ibid., 201. 
primarily due to the use of notation in composition and for transmission of musical texts. It is also related to the use of musical notation and writing in the transmission of theory. Practical teaching, however, is concerned primarily with the face-to-face transmission of knowledge based on experience. Little time is spent in lessons on the transmission of texts or theory; notation allows the student to learn a musical text outside the lesson, and although theoretical terminology and concepts may be used, the actual teaching of theory is often separated from the practical teaching of performance. Most of the teacher's time is spent on the technical aspects of sound production, and on interpretation. Although demonstration for imitation is important, verbal discourse plays a crucial role; teachers are often judged by their ability to communicate about musical matters through speech. ${ }^{11}$

Seen in these terms, traditional teaching methods in Japanese koto music may be generally described as follows: (1) there is virtually no explicit "theory" or teaching of theory as it is known in the West; (2) there are no "exercises;" the teaching of instrumental and vocal technique is integrated with the teaching of musical "text;" (3) there is no explicit conceptual distinction between "text" and "interpretation;" one learns to play following the teacher's example; (4) there is very little verbal explanation, either of technique or of musical or expressive content.

The comparison between traditional Japanese and traditional Western classical musical pedagogy is facilitated by certain similarities, particularly in the case of koto music. On the surface, especially nowadays, much seems the same: the student goes to the teacher's home, usually once a week; after waiting for the lessons of others, the student receives individual instruction from the teacher; the student learns a "piece" (a musical text) using notation; eventually the student will be expected to memorize the piece, then go on to learn another.

Based on these similarities, the student familiar with Western musical pedagogy may be quick to find differences which may be considered as deficiencies: though the lesson day is set, individual lessons are not by appointment and the time spent waiting (often two or three hours) may be an annoyance; the lack of explicit emphasis on "technique" may be considered to hold back the student's development; the lack of detail in notation may be seen as a handicap that slows one's learning of the text; if the "rote teaching method" (that is, the transmission of musical text through demonstration and imitation) is experienced or observed, it may be seen as no more than a poor substitute for the use of notation;

11 It should be noted that speech as used in teaching is often more concerned with the metaphorical expression of physical or emotional feeling than with explanation through theoretical terms and concepts. 
the lack of discourse about "theory" may be seen as preventing one from grasping more quickly the nature of the music; the teacher's insistence on playing the piece the way he or she does may seem to be an unnecessary restriction on personal freedom of expression and interpretation; finally, the lack of verbal instruction and comments on the student's playing may be seen as unnecessarily secretive and uncommunicative.

\section{Defense of the "Japanese Way"}

Negative evaluations of Japanese teaching methods, such as those seen above, eventually came under attack from a cultural-relativistic point of view. Gutzwiller, in particular, emerged as a defender of the Japanese way:

Application of Western standards in the study of non-Western music has never produced fruitful results and it is not surprising to find that Malm's evaluation of the Japanese teaching process is no exception ... it is necessary to investigate the methods of music teaching in relation to the goals toward which they lead." 12

Writing about the shakuhachi, Gutzwiller notes the importance of the social background of the ryûha and iemoto systems in Japanese music. Since schools (ryû) have, to some extent, their own repertoire and are identified with particular styles of playing, "the goal of Japanese music teaching is to teach the student the style and repertoire of a particular school and nothing else." 13 While the creation of new schools has always been possible, one of the main functions of the "ryysystem" is therefore "to preserve old music with a high degree of accuracy in the absence of anything more than sketchy notation."14

To Gutzwiller, this need to preserve, and the lack of notation capable of fulfilling this purpose, explain why there is so little emphasis on "personal interpretation:"

Personal interpretation consists of a set of changes on an original which exists outside, or above, all renditions by an individual. But since there is no such thing as an original piece in Japanese music against which an interpre-

12 Gutzwiller, Shakuhachi, 147-48. In this reverse swing of the pendulum, it is now the West which comes off poorly in comparison: In the West learning a music is an intimate, private affair which goes on behind almost shamefully closed doors... . The [Western] teacher ... is a performer who tends to look at the teaching rather as a diversion from his 'real' duties. ... The musician who is entirely a teacher hardly exists in the West [Ibid., 156-57].

13 Ibid., 149.

14 Ibid., 150. 
tation could be measured and judged, each interpretation acquires the character of a new original annihilating the previous one. The result would be constant change. Though this is, of course, a possible mode of movement... it is not the way Japanese musicians have chosen. ${ }^{15}$

Gutzwiller does not describe what actually happens in shakuhachi lessons; it is only stated that "the method used ... is imitation." ${ }^{16}$ Here, he admits a basic weakness of this method: because of the degree of concentration required from both student and teacher, "it is a method which makes bad teaching extremely easy and good teaching extremely difficult." ${ }^{17}$ Nevertheless, his overall evaluation is positive. It is also biased somewhat toward the side of the teacher rather than the student, and here one may suspect him of being overly influenced by Confucian ideology, which in Japan has generally favoured the socially superior:

It is, of course, much easier for the teacher to interrupt the student and to explain verbally ... but in doing so he transgresses his rôle as a teacher... any explanation from the side of the teacher in a medium other than music imposes a progress on the student from without. And only the progress the student has made at his own pace, without having been urged to do so, is the progress that counts. ${ }^{18}$

It is clear that this method of teaching places a heavy burden on the student... . Japanese teachers in any art ... do not believe that helping the student with his problems is always in the best interest of the student. ${ }^{19}$

Obviously reacting to Gutzwiller's criticism, William Malm has recently recanted his earlier views. In an essay entitled "Japanese Drum Lessons," he confesses that "in later years the inflexibility of those early printed words has remained to confound and embarrass me." 20 In contrast, Malm's conversion has led him to an almost mystical view, in which Japanese music lessons fulfil "ritualistic" and "spiritual" functions and seem to have little to do with learning music at all:

15 Ibid., 150-51. In contrast to this general statement, Gutzwiller notes that "personal interpretation" plays an important role in the category of shakuhachi pieces known as honkyoku (ibid., 165).

16 Ibid., 153.

17 lbid., 153.

18 Ibid., 153-54.

19 Ibid., 155.

20 William Malm, Six Hidden Views of Japanese Music (Berkeley: University of California Press, 1986), 34. 
... a Japanese lesson is ritually and intellectually structured in such a way that its ultimate goal may be spiritual rather than musical. ${ }^{21}$

... the path towards becoming a good drummer requires that one first become a good drum. ${ }^{22}$

... a traditional Japanese teacher is more a guide into a ritual whose goals may differ for different students; some may be musical, some technical, and some spiritual. ${ }^{23}$

One path [is this to Buddhistic liberation from the endless cycle of rebirth?] is in the art of drumming. ${ }^{24}$

The problem with such an interpretation is that most Japanese students - in the case of the koto, at least -nevertheless go to music lessons mainly for the purpose of learning music. It is not to "become a koto" that one pays lesson fees; all instruments can be viewed as extensions of the body without recourse to mysticism. Neither is it merely for the purpose of participating in the "ritual" of student-teacher relationships; if this were all that students desired, they could study flower-arranging or the Tea Ceremony instead. While individuals undoubtedly may have their own religious, spiritual or social agendas, nowadays most koto students go to lessons primarily to learn music. ${ }^{25}$

How, then, is this accomplished? Curiously, these positive evaluations are in agreement with a basic premise underlying the negative views already seen. This is that Japanese music lessons consist of nothing but imitation of the teacher by the student. Imitation is indeed an important part of what goes on, as we shall see, but is this all there is to it? What goes on in lessons? Is everyone taught in the same way? Does the teacher do anything other than provide a model for imitation? And if imitation is so important, is music taught this way simply for the purpose of maintaining an oral tradition in as unchanged a way as possible, as Gutzwiller suggests, or are there other musical goals involved?

21 Ibid., 23-24.

22 Ibid., 25.

23 Ibid., 26.

24 Ibid., 35.

25 Regarding the "ritualistic" aspects of lessons which Malm emphasizes, it is sufficient to note that all social behaviour is coded to a considerable degree. To those who are familiar with Japanese codes of behaviour through long exposure, they are merely part of daily life. After all, one would hardly say, because someone knocks on a door and waits for their piano teacher to say "Come in" before entering, that "almost all of [Western] personal relations have a ritualistic structure and language" (Malm, Six Hidden Views, 203; we have substituted "Western" for the original "Japanese"). 
Motegi has written about changes in the teaching of Gidayû-bushi (music for the Bunraku puppet theatre), a genre which has remained closer to traditional teaching methods. ${ }^{26}$ Though there are certain differences, her article provides a useful starting point for discussion of certain aspects of teaching and learning the koto. $^{27}$

\section{"Inside" and "Outside" Students}

As Motegi notes, there was a clear distinction, in Giday $\hat{u}$-bushi as well as in numerous other genres, between students who would always remain as amateurs and those who would become professional teachers and performers. The latter, if they were not born into a musician's family, would usually be taken into the household of the teacher around the age of six or seven; although Motegi doesn't mention the term, such students are commonly known as uchi-deshi ( $u c h i=$ house," deshi = "student/disciple"). In return for carrying out household chores and other duties, these students would receive instruction free of charge. ${ }^{28}$

We can generally distinguish, then, between students from "outside" and those who grow up "inside" the teacher's house. The latter category may include uchi-deshi, as well as the teacher's natural or adopted offspring. Inside students have greater exposure to both music and speech about music than outside students. They also seem to be taught more explicitly, and in more detail. Outside students - researchers usually fall into this category - are generally not permitted to observe the lessons of the inside students; it seems that this is where the real "trade secrets" are passed on, although even here there is a strong emphasis on development of the student's own ability to perceive and understand without being taught explicitly.

Motegi notes that the live-in system in Gidayû-bushi has largely, though not yet completely, died out since the end of the war. ${ }^{29}$ This is related to changes in society in general. As Motegi says:“ ... fewer young people born outside professional households are willing to subject themselves to what they consider the restricted and servile life of a pupil preparing to become a professional performer." 30

In koto music the situation appears to be similar. Inside students are now mainly those born into a professional household. While some teachers complain

\section{Motegi, "Aural Learning."}

27 It should be noted that many koto teachers also play and teach jiuta-shamisen, so most of the comments below will also apply to the teaching of jiuta.

28 Motegi, “Aural Learning," 97-99.

29 Ibid., 99.

30 Ibid., 104. 
that they cannot give modern young people as strict a training as they think necessary, this applies especially to outside students; changes in teaching methods, at least in some cases, apply more to outside students than to inside ones. As the live-in system becomes more-or-less extinct, it would seem reasonable to assume that a larger gap may develop between the training and exposure of those born into musician's families, and those not.

\section{Exposure to Music and Speech About Music}

One of the advantages that the live-in system allowed was constant exposure both to music, and to speech about music. As Motegi notes, "aural" (not "oral") learning comes about not only directly through lessons, but indirectly through the chance to observe and listen. ${ }^{31}$

Having the opportunity to listen to music - lessons of others, rehearsal, and so forth - is regarded as essential for learning. This was especially so before there were commercial recordings, and before the use of cassette tapes to record one's own lessons became widespread. Exposure through listening gives the student an opportunity to become familiar with pieces before learning to play them oneself. Motegi has noted that in the old days when houses were all made of wood, those eager to learn could gather outside a teacher's house and hear the sound of lessons and rehearsal..$^{32}$ For inside students, living with the teacher provides even greater opportunities. Fujii Kunie told me that she would often have pieces almost completely memorized, through frequent hearing, before ever playing them on the koto or shamisen.

Fujii Kunie: I was brought up in a professional house. If you're brought up in such a house, you're hearing music all the time, from morning 'til night. You just remember melodies from hearing, even before you play them.

For the outside student, the custom of assembling at the teacher's house on lesson days, watching and listening to other students while waiting for one's own lesson, provides similar opportunities. Although some teachers now are said to give appointments for specific times, the older practice is still followed by many who consider it essential for the students' development. Due to the reduction in number of lessons per week, however, this kind of exposure is now quite limited. Commercial recordings and tapes of lessons, as Motegi notes, are often used to some extent as a substitute for this kind of exposure; teachers sometimes worry 
about this, however, because it isolates sound from the way it is produced, and tends to lead to more uniformity. ${ }^{33}$ Even in koto music (where the degree of fixity is much greater than in Gidayû-bushi), the musical "text" and the teacher's "interpretation" are not completely fixed; it is considered to be quite normal that things may vary in subtle ways from day to day, and over time. For this reason, constant exposure and careful listening are necessary for the student to be able to perceive and understand the limits and possibilities of variability. Even today, the waiting period gives outside students a chance to develop their listening skills and become more familiar with the teacher's way of playing. ${ }^{34}$

Exposure to speech about music is also beneficial for the student's development. Here the inside student has a distinct advantage. Since speech about music is not highly regarded in the lesson context itself, being inside gives the student the opportunity to listen and observe as the teacher discusses things with family and colleagues. The student may hear talk about what went well or poorly at rehearsal or concert, the strong and weak points of different musicians, comments about different pieces or the development of different students, and so on. As Motegi has noted:

Being with his teacher day and night, sharing his work and conversation, listening to discussions on life or art between the teacher and his colleagues, watching how problems were solved, and perceiving the individuality of each person in these encounters, the pupil's eyes and ears slowly received their training in the context of the teacher's home and social circle. ${ }^{35}$

Such exposure to speech about music is largely unavailable to the outside student, at least at the beginning. However, as the student reaches a higher level and becomes more involved in performance activity and helping out the teacher in various activities, contact with the teacher is deepened, and exposure to this kind of discourse is likely to increase.

33 Ibid., 105.

34 There is, therefore, nothing mystical or ritualistic about the waiting period. It is not because (as Malm suggests) one needs to "develop a patient sense of time" that students gather and wait; neither is it to allow the "spirit of the other players" to "permeate the ear and mind," nor for "absorbing the atmosphere," nor to indulge in something "akin to meditation" (Malm, Six Hidden Views, 25). Rather, it is simply that this has always been the best way to get enough listening exposure; if one were to rely solely on one's own lesson time, the road to learning would be even longer and more expensive.

35 Motegi, "Aural Learning," 98. 


\section{“Ampu-geiko:” Learning by Memory}

The traditional method of teaching koto is primarily one of demonstration and imitation, conducted without notation. Motegi calls this "direct aural learning," a term that does not carry the negative implications of "rote learning." This type of lesson is now referred to by some teachers as "ampu-geiko" (ampu= "memorization;" keiko = "practice, training") in contrast to lessons which are based on the use of notation. ${ }^{36}$

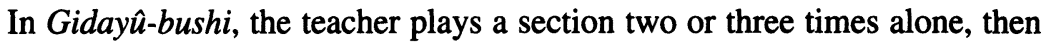
several times with the student, then finally the student plays alone. Motegi notes that these sections are usually ten to fifteen minutes long; this shows the need for constant exposure as well as highly developed listening skills and memory ${ }^{37}$ The process is similar in koto music, although the length of what is played depends largely on the ability of the particular student.

"Imitation" is often regarded rather negatively in the West; the concept is coloured by ideas concerning individuality, originality and expression, and imitation is often relegated to the negatively-valued side of a dichotomy (e.g. "creative/imitative," "original/imitation"). As we have seen, teaching music without notation, by demonstration and imitation, may be seen simply as an inefficient way of transmitting a musical "text." As Linda Fujie notes, however, imitation requires the almost instantaneous intellectual and psychological processing, by the student, of aural (and visual) phenomena produced by the teacher. The student then produces his or her own version, which is meant to be as close to the model as possible. ${ }^{38}$ One might add that this also requires development of the technical and physical ability to reproduce, quickly and accurately, that which has just been mentally processed. This is not easy. It requires highly developed listening and performing skills, a very good memory, and an almost intuitive understanding of musical structure.

The traditional kind of training is therefore concerned not only with the transmission of musical text, but also with the development of such aural, mental and physical skills. Here, it must be noted that it is not, as Gutzwiller suggests, just to maintain an unchanging oral tradition that emphasis is placed on listening and imitating in lessons. Rather, since the model or text may vary in subtle ways, a certain amount of mental flexibility and adaptability must also be

36 " $A m p u$ ", as it is now written, literally means "memorizing musical notation," but this should not be taken to imply that music was traditionally memorized from notation.

37 Ibid., 99.

38 Linda Fujie, "The Process of Oral Transmission in Japanese Folk Performing Arts: the Teaching of Matsuribayashi in Tokyo," in Tokumaru and Yamaguti, eds., The Oral and Literate, 231-38. 
developed, in order that the student be able to pick up and react to the small changes that may occur on any given occasion.

To teachers, the development of such skills comes ahead of individual expression. This is not to say that individuality is not allowed, but rather that there are other priorities in the learning process. As Motegi tells us:

... pupils eventually learn the art of careful listening and exact imitation through years of practical experience. Only after they have reached an advanced stage in their training do they then learn to play in their own styles, revealing their own personalities. ${ }^{39}$

My own teachers expressed similar thoughts. To paraphrase what Fujii Kunie told me on several occasions:

The way I sing is different from the way my mother, Abe Keiko, sings. The way my son Hirokazu sings is also different. You'll be able to have some freedom in the way you play and sing, eventually, but first you have to master control of your voice and the instrument, and understand the music.

Motegi notes that, for a variety of reasons, this type of teaching without

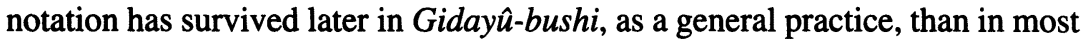
other types of traditional music..$^{40}$ In koto music, most older performers learned this way, and inside students are still sometimes taught in this manner. Fujii Kunie, for example, told me that she learned by ampu-geiko from her mother, Abe Keiko, without using notation at all. Her son, Fujii Hirokazu, describes his own early experience:

At first, I couldn't read notation, so I learned everything by memory ... by ampu-geiko, every day. Also, if you learn every day, the time you spend playing is also different. As soon as a lesson was finished, I had to practice right away or I'd forget.

For most students today, notation has largely taken over the function of transmitting a basic musical text. For these students, the first step in the process described above (demonstration by the teacher alone), is no longer a necessary part of the lesson, and memorization is carried on outside the lesson. The other skills, however, are still strongly emphasized, and these are learned mainly through the practice of playing with the teacher.

39 Motegi, "Aural Learning," 99.

40 Ibid., 97. 


\section{Playing Together}

In the first koto lesson, a modern student will likely receive a few minutes instruction in the proper way to sit, the way to address the teacher, the placement of the tsume (picks, literally "nails") on the fingers, the positioning of the hands, and the rudiments of the notation system. Then the teacher and student begin playing the first piece together.

Playing together involves direct musical communication from teacher to student. From the start, the student must learn to listen and match his or her own playing with that of the teacher. Correct rhythm and pitch are learned largely without the mediation of speech or "theory." In some ways, playing together is an extremely effective teaching technique. It is much easier, for example, to learn proper timing by listening and matching the teacher's rhythm while playing together, than to play alone, stop, and then try to correct one's playing on the basis of a verbal critique.

Playing together does not, however, involve only one-way imitation of the teacher by the student. Rather, the teacher has numerous ways of actively conveying information to the student. For example, while playing with the student - and also when pausing and demonstrating to the student - the teacher may use musical means of communicating about the music. Accents, dynamic contrasts, subtle changes in timing and so on, may be exaggerated in order to help the student to perceive them more readily. While playing together, a teacher may play a particularly difficult passage more strongly than usual. Sometimes a teacher will play the koto part together with the student but not sing, joining in - as a way of giving emphasis - only where the student is having problems with the vocal melody. Another musical means of communicating is that of simplification; for example, a subtle vocal melodic movement may be sung more "squarely" in order to clarify the basic outline to the student.

Speech also may be used by the teacher for instruction or correction while playing together. Without pausing, the teacher may call out the next string number, tell the student to adjust the bridges when the strings have come out of tune, tell the student he or she is singing too high or too low, correct the student's pronunciation, and so on.

In a similar way shôga, a form of oral representation of instrumental melody, also may be used while playing together. Using shôga the teacher may correct the student, fill in rhythmic pulses, tell the student to use a particular technique by calling out the corresponding shôga syllable, or sing the part of another instrument, all while continuing to play with the student.

The student and teacher sit facing each other. This gives the sighted student the opportunity to observe the teacher's movement and use of the body in sound 
production, either while the teacher demonstrates or while playing together. Exaggerated motion may also be used as a visual means of communicating to the student.

In the early stages, and while a student is learning a new piece, the teacher may often pause to correct or comment, to give explicit verbal instruction on technique, to demonstrate, or to start again after the student becomes unable to continue. Playing together, however, is the central part - the goal and ideal - of the lesson. As the student improves, the amount of stopping for explanation and demonstration decreases. Likewise, the amount of instruction given while playing together (i.e. without stopping, through the various means described above) also decreases. For advanced students, and even for less-advanced students once a particular piece is more or less mastered, a lesson may consist of only the opening greeting that signals the beginning of the lesson, playing the day's piece or section together with the teacher once or twice, without pause or comment, and then the salutation that ends the lesson. ${ }^{41}$

Here, it is interesting to note that although the term "keiko" is often now translated as "lesson" when referring to music, the original meaning is closer to "practice" or "training." Thus, from the student's point of view, the term tends to imply "practising together with the teacher," rather than "being taught." (In contrast, the term "keiko" is not generally used in reference to instruction in Western classical music; the English word "lesson" is used instead).

Once the student has mastered the instrumental part being learned (and the song, if it is a vocal piece), the teacher may accompany with a second part on koto or shamisen. In this way, the learning of the part for one instrument is integrated smoothly into the learning of ensemble performance. Indeed, the constant emphasis on playing together means that ensemble performance skills are learned from the very beginning.

\section{Segmentation and Articulation}

As Motegi notes, the kind of traditional training described above, in which the teacher presents musical text segment by segment; requires an almost intuitive grasp of musical structure:

The basic purpose of aural learning with little if any dependence on notation is to help pupils develop a clear understanding of the music's fundamental

41 As Gutzwiller has said (Shakuhachi, 153), depending on the teacher and the student, the result can range from a rather lackadaisical running-through of the material, to music-making at its best; in the latter case, it is indeed inspiring for the developing student to be playing together with a highly accomplished musician. 
structure... . Once this is accomplished, it becomes much easier for him to learn new pieces since he is thereby able, to some extent, to anticipate the arrangement of melodic patterns. ${ }^{42}$

Motegi is referring specifically to Gidayû-bushi, in which there are a number of named melodic patterns. As Tokumaru has shown in connection with the shamisen genres Icchû-bushi and Gidayû-bushi, the ways in which the teacher divides the piece, in the traditional method of teaching, convey certain information about musical structure. ${ }^{43}$ Gidayû-bushi shamisen players tend to talk explicitly about segmentation; on the other hand, jiuta-shamisen musicians who are also usually koto teachers - tend to not talk about segmentation. ${ }^{44}$

The reasons for this are, in part, related to the nature of musical structure in the different genres; this matter is beyond the scope of the present paper. We may note, however, that according to Fujii Kunie, the length of segments which the teacher would present in the traditional method of teaching koto (or jiutashamisen) would vary considerably according to the ability of the student. In her own case, she said that because she had virtually memorized pieces by listening before ever trying to play them on the instrument, she was able to handle very long segments at once; segments that included numerous internal articulations or divisions. For a student with little exposure and a poor memory, the segments would be much shorter.

Although this way of teaching is little used nowadays, details of segmentation and articulation are still conveyed implicitly through the places in which a teacher begins a demonstration of a passage, or tells the student to start after pausing. There is usually no talk of "units," "segments," or "phrases," and there is also no traditional terminology for these. However, my teachers often used the term atama ("head") to indicate a point which is the beginning of a short melodic pattern; for example, telling me to place a slight accent on a particular tone because it was the atama. Through the selection of starting points, a sense of articulation - perhaps a better word than "segmentation" - is communicated through the teaching method.

It should be noted that modern scores often indicate something like "measures." However, these are simply for convenience and have no relation to the natural articulations of the music. Apparently some teachers today will ask

42 Motegi, "Aural Learning," 102.

43 Tokumaru Yosihiko, "Le mouvement mélodique et le système tonal de la musique de syamisen," Canadian University Music Review, no. 1 (1980): 66-105. Tokumaru, "The Interaction of Orality and Literacy," 120-22.

44 Tokumaru, "The Interaction of Orality and Literacy," 120. 
students to begin at the beginning of a "measure" or a line, regardless of whether this makes musical sense or not. And my teachers had come across students who were too dependent on notation, who thought in terms of the "lines" and "measures" in the score and were not aware of the natural articulations. Musicians who have been brought up in more traditional ways are quite critical of this kind of thinking. The extent to which this happens is not clear, but there is certainly a possibility that use of scores, recordings and cassette tapes, combined with the demise of traditional ways of teaching, can lead to a failure to understand musical structure. Perhaps this is one area in which development of formalized music theory, based on traditional teaching methods, could be useful to practising musicians.

\section{The Use of Notation}

The traditional teaching process, as described above, was not based on the use of notation. During the Edo period, transmission of koto music was officially in the hands of the blind musicians of the Tôdô-za; they, of course, had no need for notation in learning or teaching, nor in composing. ${ }^{45}$ For amateurs, numerous scores of koto kumiuta (and pieces classified as tsukemono; "attached things") were printed from the late seventeenth century onward. Although these were widely distributed, there seems to be no reason to think that they were actually used in lessons; such scores are generally considered to have been only for reference outside of the learning context. For this reason, it was not necessary for the notation to be "complete;" the Sôkyoku-taiishô (1779), for example, includes text but no musical notation for the vocal part, which had to be learned directly from the teacher.

It must be emphasized that "authority" in traditional Japanese music does not reside in a score as "text," but in the teacher as representative of a musical lineage. Even today, learning must come through a qualified teacher to be considered truly authentic. For example, some highly competent and well-established koto musicians have performed and recorded koto kumiuta which they apparently did not learn directly from a teacher. While they may be lauded for their efforts to bring life into a seldom-performed and seldom-taught genre, there are also voices who criticize them for lack of authenticity. Such attitudes, of course, are bound up with ideas concerning the social control of music-making. In any case,

45 The Tôdô-za was a professional guild for blind men. Originally an organization for biwa players, it received the official protection of the Tokugawa military government during the Edo period, and occupational categories were expanded to include koto and jiuta-shamisen teaching, as well as acupuncture, moxa and massage (Nishiyama Matsunosuke, "Tôdô," Ongaku Daijiten, vol. 3 (Tokyo: Heibonsha, 1960), 2035-36). 
there is never any need for musicians to prove fidelity to a score, because authority is not associated with notation.

In its traditional use, then, notation for the koto is more "descriptive" than "prescriptive." The "description," however, is for the purpose of reminding one of something very familiar that has been learned by memory; for this reason, notation does not need to be very detailed. All musical notation, of course, being symbolic representation, is incomplete. Koto musicians are very aware of this, not from the point of view of semiotic theory, but through daily experience. Musicians, especially those who have learned in more traditional ways, are very conscious of the distance between what is written and what is performed:

Fujii Hirokazu: Don't think that the score shows everything, it's only like a kind of memo. It's not the kind of music that can be written in a score anyway... . We don't play these written characters ... we play music that can't really be shown in a score.

Fujii Kunie: You can use the score to check things, but you can't really learn the music from it. It just gives you a hint ... You can't write these things [rhythmic nuances] down. In the score, these [strokes] are all even, right? Some people actually play it that way, but that's pretty boring, isn't it, not very musical at all ... like a little child.

These days, musicians who were trained in more traditional ways often do not have scores for their own versions of pieces. Fujii Hirokazu told me that his family was gradually compiling their own scores because students kept asking for them. Even these, however, do not represent rigidly "fixed" versions of the pieces, since there are variations within the family itself. When scores of the family version were not available, I was often told to get those edited by Miyagi Michio, which are published and commonly available. Then my teachers would show me what alterations were necessary to the vocal and instrumental parts in order to perform it their way.

The use of notation in learning the koto is now fairly widespread. Without notation, it would be hard to imagine how one lesson per week would be sufficient for either student or teacher. While some musicians even perform using notation, this is generally tolerated more for modern pieces rather than for traditional ones. As Tokumaru notes, shamisen musicians are generally expected to show that they have internalized the piece by memorizing it, even if notation was used in learning. ${ }^{46}$ The same applies to traditional koto musicians. My 
teachers were quite critical of those who did not memorize a piece for performance, and would not allow their own students to move on to a new piece before the one being learned could be played satisfactorily from memory.

Standard koto notations operate according to fairly simple principles. There are symbols which represent the thirteen strings and also certain special playing techniques. These are placed in relation to some kind of spatially-oriented representation of musical time (equally-spaced lines, circles, or some kind of grid). Since the notation relates directly to the strings of the instrument and playing technique, and the spacial representation of rhythm is quite easy to grasp, little explanation of the notation system is required for the beginning student. By playing with the teacher from the very beginning, the student learns to interpret the notation according to what is heard, rather than to imagine a desired sound according to what is written. This orientation is crucial to an understanding of the function of notation in teaching and learning.

Although notation is now quite common, its use entails the risk that the student will not sufficiently develop the necessary aural skills. My teachers were quite concerned lest I become too dependent on notation, and develop my image of the music from notation rather than by listening:

Fujii Hirokazu: You should try to remember the piece by ear before you look at the score.

Fujii Kunie: You should listen a lot first, even a record is OK. Try to get the music into your ears. It's best if you can remember it before you look at the score. If you begin by just looking at the score, you won't be able to understand the melody.

When I first began studying with Fujii Kunie, I usually went to lessons with a score and played from it until I had mastered the piece enough to memorize it. Gradually, however, I noticed that most of my fellow students did not use notation in their lessons. Generally, they memorized the section of the piece that they wanted to work on that week, prior to the lesson. To do this, one told me, she would not only use a score, but also try to get a recording by Fujii Kunie or her mother, Abe Keiko. By listening repeatedly to the recording, she could come to the lesson already knowing the teacher's version, or something quite close to it. The lesson, then, was a chance for the student to concentrate on picking up the nuances of the teacher's way of playing. Only occasionally did one of the other students play from notation in the lesson itself, and this generally seemed to be from lack of preparation. 


\section{Shôga}

In contrast to notation, another form of symbolic representation of sound played a major role in more traditional methods of teaching, and continues to be important today. This is a form of oral (sung) representation, ${ }^{47}$ in which instrumental sound is represented through a combination of musical (pitch and rhythm) and linguistic elements (the syllables of everyday language). Shôga (which literally means "that which is sung") ${ }^{48}$ is now used as a generic term by Japanese scholars for such systems, which have been widely used in the teaching of many types of traditional Japanese music.

A full discussion of shôga in koto music, which is fundamental to an understanding of the musician's perception, is beyond the scope of this paper. Here, let us simply make several comments on its use in teaching, an aspect which, as Fujita has pointed out in his article on shôga for the Nôkan (the flute used in $N \hat{o}$ ), has been generally neglected in scholarly writings. ${ }^{49}$

For certain instruments and types of traditional Japanese music - e.g. the Nôkan and the wind instruments of Gagaku - there is a well-established practice of teaching an instrumental part through shôga before it is taught on the instrument. ${ }^{50}$ That is, students will be taught first to sing, using shôga, a section of the music. Once they can do this, they are taught to play it on the instrument. Then the teacher may continue on to the next section in the same manner. For such instruments, therefore, the teaching of instrumental sound as shôga is moreor-less formalized as part of the overall teaching process.

However, as Yokomichi has pointed out, this is not the case for koto (and also jiuta-shamisen). Students begin the lesson playing the instrument; shôga is used by the teacher to lead and correct, but the student is not normally made to sing the shôga. ${ }^{51}$ Koto musicians, although usually quite familiar with shôga and comfortable with its use, generally say that they did not learn it formally and they do not teach it to students. Rather, shôga is something which is absorbed through experience of its use in the learning process.

47 I avoid the term "oral notation," which is self-contradictory. "Oral representation" conveys the symbolic nature of shoga, while avoiding confusion with graphic forms of representation.

48 Kamisangô Yûkô, "Oral and Literate Aspects of Tradition Transmission in Japanese Music: with Emphasis on syôga and hakase," in Tokumaru and Yamaguti, eds., The Oral and Literate, 288.

49 Fujita Takanori, "Kuchishôga: the Vocal Rendition of Instrumental Expression in the Oral and Literate Tradition of Japanese Music: with Emphasis on the Nôkan," in Tokumaru and Yamaguti, eds., The Oral and Literate, 239-51.

50 Yokomichi Mario, Notes to record collection Kuchishôga taikei (nihonno gakkino sorumizeeshon) (CBS-Sony OOAG-457-61, 1978), 15.

51 Ibid., 15. 
As mentioned above, shoga may be used by the teacher while playing with the student to correct (after the student has made a mistake), to lead or guide (calling out the syllable of the next technique to be played), to keep track of timing, or to fill in the part of another instrument. The teacher also may stop, and then correct the student using shôga, either by singing or just by speaking the syllables. After pausing, the teacher may use shôga to tell a student where to begin again; for example "begin again at sha-sha-kororin," or "take it from shan-ten-shan-ten." Through such use, the student gradually learns to associate instrumental sound with its oral representation in shoga.

Although shôga itself is not taught, it is also possible to teach koto or jiutashamisen melodies without playing the instrument, through the use of shôga. Fujii Kunie told me that sometimes she would have lessons without using the instrument at all. Sometimes she would play, while her mother would teach her using only shôga:

Fujii Kunie: ... for example, when I was young, my mother would sometimes teach me while she was sewing or doing something else. I'd be playing, and she'd teach me by mouth [i.e. singing shôga]. Sometimes neither of us would play, and just do the entire lesson by mouth.

In addition to its use in lessons, shôga also may be used for practising. According to Fujii Hirokazu, he and his wife often use shôga to practice (usually jiuta-sôkyoku pieces, for shamisen and koto), while driving in the car. As Yokomichi has noted, shôga also may be used in ensemble rehearsal prior to a concert. Sometimes, when the piece is a traditional one which is well known by the musicians, they may not actually practice together before the concert. In such cases, they may use shôga to run quickly through a piece (or sections of a piece) before the performance, without actually playing the instruments. ${ }^{52}$ Koto and jiuta-shamisen musicians have told me that such use of shôga is common, particularly when musicians, accustomed to slightly different versions of a piece, must decide how to play it on a given occasion.

Thus shôga, through frequent use in lessons and other situations, is learned by the student. However it is not just a learning device which is forgotten outside of lessons; as Kikkawa and others have pointed out, shôga is fundamental for both memory and perception. ${ }^{53}$

52 Ibid., 16.

53 Kikkawa Eishûi, "Shôga (gakki-senritsu-shôhô) no rekishi to genri to kinô; shamisen to koto no shôga wo chûshin toshite," Musashino-ongaku-daigaku kiyô 7 (1973): 1-23. Reprinted in Kikkawa, Nihon ongaku no biteki kenkyû (Tokyo: Ongaku no tomo-sha, 1984), 249-84. 


\section{Speech about Music}

It is almost a cliché, in dealing with traditional Japanese music, to say that teachers don't like to talk about music, and especially don't like to be questioned about it. A Westerner planning to go to Japan to study traditional music is very likely to be advised to not ask too many questions. Burnett states bluntly that "traditionally, the student does not ask questions ...." ${ }^{44}$ Although it is commonly thought that the non-Japanese student may get away with asking a few questions during a lesson (Japanese scholars sometimes think that this gives the "outsider" an advantage), the teacher may be quite uncomfortable with this. Other students generally do not ask questions. Koto musicians generally acknowledge that many teachers do not explain much verbally.

This does not mean that musicians do not, or cannot, verbalize about music. Neither does it mean that they do not speak at all during lessons. However, the nature and conditions of discourse, as Nattiez has noted, are determined by cultural values and practices surrounding both discourse in general and discourse about music in particular, by the circumstances and context of the discourse, and also by the personalities of those involved. ${ }^{55}$

For traditional koto musicians, the lesson is regarded as a context for learning music. As Motegi has emphasized, "direct aural learning" has traditionally been the main means of accomplishing this. ${ }^{56}$ Speech about music is generally minimal. When it is used in lessons, it is generally directed toward very practical matters: explaining the use of the hands; explaining the production of certain techniques; correction of mistakes in pitch, rhythm and technique; correction of pronunciation in singing; indicating approval of something done correctly, and so forth. Much of this is done using terms from everyday language, which may have special nuances when used for music; there are very few terms which are used only in connection with music.

If "theory" is to be understood as some kind of more-or-less formalized, explicit, verbal explanation of aspects of musical systems, then it may be said that there is very little "theory" in the teaching of traditional koto music. Koto musicians (and many Japanese musicologists) quite readily characterize sôkyoku (koto music) and also jiuta as "music without theory" ("riron no nai ongaku"). This characterization is to be understood in the sense that the term "theory" is

54 Henry Burnett, “An Introduction to the History and Aesthetics of Japanese Jiuta-tegotomono," Asian Music 11/2 (1980): 27 (note 12).

55 Jean-Jacques Nattiez, Music and Discourse; Toward a Semiology of Music (Princeton: Princeton University Press, 1990), 186-97 (especially 190-92).

56 Motegi, "Aural Learning." 
usually used in Western classical music. This is not to say that there is absolutely no "theory" dealing with koto music, nor that there is no "thought about music." However, thought about music is generally not formalized or systematized, and verbal explanation is not regarded as very important in the teaching of this music.

For koto musicians, it seems only natural that some things can't easily be expressed verbally:

Fujii Kunie: There are some things that just can't be explained. This music is something that's been passed on, traditional. We learned it and we pass it on through the sound itself, naturally, without a lot of theorizing or talking about it.

Generally, speech about music is used more in the beginning stages of learning. As mentioned above, lessons for advanced students often consist of little more than playing the day's piece or section together with the teacher a couple of times, without pause and without comment.

This kind of teaching without verbalization is common in traditional Japanese music, especially for advanced students. As Nagauta virtuoso Yoshimura Gorôji notes:

... while you're being scolded or put through the mill by the teacher, you have hope, but when you're no longer told anything, that's the worst ... what hits you hardest, is when you're told 'from this point on, figure it out for yourself.' It's probably from this kind of painful experience that the real art and guts of a pro are born .... ${ }^{57}$

\section{"Nusumeba ii;" "if you can steal it, that's OK"}

Yoshimura's comments reflect one of the dominant values related not only to the use of speech in teaching, but to the teaching of music in general (i.e. including other methods described above). This value is expressed in the common saying "nusumeba ii," which, loosely translated, means "if you can steal it, that's OK." It is commonly said that paying fees and receiving lessons

57 "Shishô ni shikararetari shigokaretari shite iru uchi wa mikomi ga arimasu ga, nanimo iwarenaku nattara, mô dame desu ne...mi ni kotaeru no wa, 'sorekara saki wa jibun de kangaero' to iu oshiekata desu. Sonna kurushii keiken no naka kara hontô no puro no gei ya konjô ga umareru no kamoshiremasen." Yoshimura Gorôji, "Shishô to deshi; konjaku no kan," Kikan Hôgaku 32 (1982): 52. 
does not really entitle students to be "taught;" rather, it allows them the opportunity to "steal" the teacher's art. The onus is generally seen to be on students to take what they can.

Fujii Hirokazu: We have some 'secret techniques, ${ }^{58}$ used only by Abe Keiko, Fujii Kunie, myself. You're not supposed to ask about these. We don't teach them to students, but it's all right if you can steal them. Some of these things we teach within the family, of course, but even then a lot of it is not taught. Fujii Kunie 'stole' from Abe Keiko, and I do the same thing. We just have to pick these things up on our own.

If the attitudes expressed by the phrase "nusumeba ii" emphasize the development of self-reliance and the student's perceptive skills, they are also related to ideas concerning the control of music-making and learning. While such attitudes place a great burden on the student, as Gutzwiller has pointed out previously, they also unfortunately allow those musicians with little talent or aptitude for teaching to retreat behind a mask of Confucian ideology. At worst, koto lessons can consist of nothing but a perfunctory playing together of the day's piece; the student has little recourse but to put up with it and hope for better, or leave music entirely, since switching to another teacher is out of the question.

Students, in fact, often do appreciate being told or shown things. In private conversation they will often praise a teacher for his or her ability to teach explicitly, whether through use of speech or other means. And those who manage to come into contact with more than one teacher, for example by entering a university program in traditional music, certainly compare and evaluate their teachers in private.

However, students nevertheless generally refrain from asking questions of the teacher. This is, of course, related to cultural values concerning status and the student-teacher relationship. On the other hand, the difference with Western ways has probably been exaggerated. If one considers the way children and even adults learn music in the Western classical tradition - that is, learn singing and playing, as opposed to history and theory - one may wonder whether such questioning on the part of the student is really such an important thing. Maybe "questioning the teacher" is done in the West mainly by university students confronted with the unfamiliar. In any case, perhaps a certain reticence on the part of the student is not always such a bad thing. As a Canadian friend of mine who specializes in teaching a certain type of non-Western music once said to me: 
You know, I often used to get frustrated because my teacher wouldn't explain things clearly enough. But now that I'm teaching Western students, I get really annoyed when they keep on asking questions. Sometimes I think to myself, 'why don't they just shut up, and use their ears and their brains for a change.'

\section{"Text" and "Interpretation;" Fixity and Change}

It has been noted above that there is no conceptual distinction made, in the teaching/learning process, between "text" and "interpretation." The student does not learn fixed musical "texts," and parallel to but somewhat independently of these, means of "interpreting" them. Rather, text and interpretation are integrated in the teaching process, and these are learned together.

This does not mean that musicians are unaware of differences in the way people play and sing; differences that in the West would be attributed to "interpretation." There are differences between schools and sub-schools, individuals within the same group, and even performances by the same individual. Musicians are acutely aware of these differences. While studying the koto and shamisen, I was often told things like "don't play it that way or you'll sound like [X-person or Z-ryû]," or "we do it this way." There clearly exists an awareness of something that could be called "interpretation," and this applies to individuals as well as to schools and sub-schools.

The difference is not in the lack of awareness of "interpretation," but rather in the lack of a concept of a fixed musical "text" that lies, solid and immutable but intangible, somewhere out beyond the realities of everyday performance and human life (or, equally solid but perhaps less immutable, within the patterns of ink on paper in a musical score). This is why one can speak loosely of "pieces" (kyoku) in traditional Japanese music, but not of "works" (sakuhin). Names of items of repertoire indicate some kind of concept of an "object," or set of configurations or patterns that are common to different manifestations of the "piece;" to look at this another way, we can say that a name is used to categorize very similar but slightly different things (different versions or performances of the "piece"). Such "objects" are not considered to be fixed and immutable, however, but rather are subject to continuing if subtle transformation. To koto musicians, such variance is seen to be only natural, since music is learned and performed by human beings, and not by machines. This kind of view seems to stem mainly from observation of the real world, through lived experience, rather than from philosophical speculation.

Given that there is no concept of a "fixed text," then, we can understand that there is no clear conceptual distinction between "text" and "interpretation" in 
teaching. The distinctions that are made explicitly are between "the way we do it" and the way others may do it. Within the group, "text" and "interpretation" are taught as one thing.

Good teachers, however, show clear awareness of levels of interpretation. What the student learns at first, in the early stages of study, is what might be regarded as a "basic version" of the piece. This version, however, is not a pure, raw "text," denuded of all interpretive elements, but rather the basic interpretation of the particular teacher or group. It contains all the basic elements that distinguish the teacher's or group's version from those of others. It must be emphasized, however, that even such a "basic version" is not entirely fixed; it may vary slightly from day to day, week to week, student to student, teacher to teacher, and also over the years.

As the student improves, he or she is taught versions of pieces that are more refined. The more advanced elements of interpretation are incorporated into more advanced pieces; here again, there is no overt conceptual distinction between "text" and "interpretation." However, the student is also expected to incorporate some of these elements into the performance of pieces learned earlier, as the following incident shows.

Once I was observing a lesson in which the student was going to play the jiutashamisen piece Kurokami. This piece is usually learned fairly early, because the shamisen part is very simple, but in fact it is quite difficult to perform well precisely because of its extreme simplicity. The student had learned the piece several years before and had not performed it since. She had recently been asked to play the piece in a concert, and although the concert was organized by a group with which her teacher was not directly affiliated, she wanted to go over the piece with the teacher prior to the event. After she had played for fifteen or twenty seconds, the teacher interrupted angrily, saying, "What do you think you're doing? You're playing that exactly the same way you did five years ago! Haven't you learned anything in the meantime? You sound like a beginner!" After several minutes in this vein, the teacher said, "All right. Well, now I'll show you what touches you can add ${ }^{59}$ to make this better." The teacher then proceeded to give explicit instruction in certain kinds of vocal nuances to be added to the version that the student already knew.

I spoke to Fujii Hirokazu about the question of change and transformation.

Generations change, people's way of thinking changes, the way of life changes. There's hardly any such thing as a purely Japanese way of life any

59 “Gei wo ireru" ("to add touches"). "Gei" means "art," “tricks" or "accomplishments," and is used here in the sense of "artistic touches." 
more. We eat in a kitchen, we drive cars ... all these things have an influence. As things change, people change ... what's inside their heads changes, so it's only natural that music changes too. Nevertheless, even while things change, one has to maintain a minimal level of tradition; after all, this is socalled 'traditional music.' But even while maintaining the tradition, one should always be thinking of how to improve things, for example where to breathe, making small changes in the melody. But this kind of judgement must be based on ability which comes from long experience. If you just do what you want, the tradition will break down.

It's difficult to just maintain the tradition, and it's also difficult to improve on it. When performing, I feel it necessary to maintain the tradition I received from Abe Keiko and Fujii Kunie, but when teaching, it's also necessary to find something, in the classics, that modern young people can relate to. You can't just tell them 'we do it because it's from the Edo period.' Even if you only try to maintain the tradition as it was, it's going to change anyway.

We don't try to always do the same thing. There's a difference, if you've been playing for ten, twenty or fifty years. For example, Fujii Kunie has been playing for fifty years, whereas I've only been playing for twenty. The way you feel about things changes with age, so you make changes. When teaching, what you teach depends on the student; the piece that you teach to someone who's been playing for twenty years is not the same as that which you teach to someone who's been playing for fifty years. When you go back to play a piece again, before you make your own changes, first you go back and re-learn it from the teacher. Then you'll probably notice 'ah, this or that is different from ten years ago.' Naturally, you should try to do it the way the teacher does, but if the teacher is thirty or forty years older, it's just not going to sound the same, is it? It would sound strange if a thirty year-old tried to sound like a sixty year-old. You might be able to make a copy, but it won't have any content. So of course things are going to change.

\section{Conclusions}

Traditionally-oriented teaching methods, particularly as exemplified through the now almost-defunct "live-in" system, have emphasized development of skills of perception and memory. A high level of technical skill is demanded, but "technique" is not separated from "music," and the teaching of technique is 
integrated into the teaching of musical "text." ${ }^{10}$ Perception is largely unmediated by explicit, formalized "theory," but although direct perception is emphasized, this does not mean that perception is completely "pure" and unmediated. Speech about music, in everyday language and with the use of a few technical terms, conditions perception to some extent; terminology, and the ways in which language is used, can provide the researcher with certain essential clues about the ways in which music is conceived. Non-language mediation, however, is more important in lessons, and also can tell us a great deal about what is important musically. Purely musical means of communication which may be used in the lesson context include exaggeration, simplification, segmentation, accentuation, etc. In addition, the oral representation of instrumental sound (shôga) is especially important in mediating perception.

Notation is often used nowadays, but in more traditionally-oriented teaching it plays only a secondary role. The emphasis is on hearing rather than reading. The writing of music is conditioned by the context of its use; notation is a memory aid for something learned aurally. To musicians trained in more traditional ways, notation should be interpreted according to what is heard, rather than sound being produced according to what is read. For these reasons, notation must be used with caution as a research tool; one cannot necessarily base analytical conclusions on "what it says in the score," and one cannot assume a correspondence between what is written and what is played on any given occasion. One must be aware of the gap between what is written and what is done - a gap that semiotic theory tells us must be there, and that musicians' experience tells them is there.

While musicians are very aware of interpretation, and of minute differences between interpretations, there is no underlying concept of a fixed musical "text." Names of pieces indicate some kind of conceptualization of an "object," but this is not something that is fixed and immutable. Slow and subtle change is an accepted part of tradition. Teachers adapt what they teach to the student and

60 As Gutzwiller has pointed out for the shakuhachi, the order in which pieces are taught (an order which is more-or-less fixed in various ryûha) incorporates a gradual progression in technical difficulty (Gutzwiller, Shakuhachi, 151-52). Since the number of techniques used in traditional koto music is quite limited, and these are (for the most part) encountered in the first year of study, it is possible to progress through pieces of increasing difficulty without any specific focus on technique in the teaching process. Nowadays, there are books for beginners which include exercises and simple pieces to introduce the student to basic techniques before entering the classical repertoire. In addition, some teachers may suggest to their students certain kinds of exercises to overcome particular technical problems. 
the occasion, even if only in subtle ways. Some teachers may insist on almost exact imitation, and the social control of music-making may extend at times to the smallest details of interpretation. Nevertheless, the image of a completely unchanging tradition, within which there is no possibility of personal expression but only complete subservience to the authority of the teacher and the tradition, is a serious misrepresentation of what happens in the highest levels of traditional music-making.

In theoretical terms, the lack of a completely fixed text means that care must be exercised in the choice of "objects" for analysis, and the levels at which those are regarded. One must adapt one's choices to the questions being asked, as well as adapting one's questions to the material. For some questions, any version of a piece may be sufficient. For others, it may be necessary to compare detail in several versions; in this case, such comparison must take into account the lineages and ryûha to which different performers belong, since interpretation is first that of the ryûha and only secondly that of the individual. Yet other questions - for example Loeb's attempt to establish an "Urtext" score of "Yatsuhashi's Midare" on the basis of modern scores and performances - may be completely irrelevant. $^{61}$

Appendix: Glossary of Principal Japanese Terms (All important terms are explained in the main text, usually at their first appearance)

ampu-geiko - the traditional type of lesson in which music is taught by demonstration and imitation (from $a m p u=$ "memorization;" keiko = "practice, training")

atama - literally "head;" indicates beginning of a short melodic pattern

biwa - 4-string lute-type instrument

gagaku - ancient court and shrine ensemble music

Gidayû-bushi - genre of music for the Bunraku puppet theatre; voice accompanied by shamisen

61 David Loeb, “An Analytic Study of Japanese Koto Music," Music Forum 4 (1976): 335-93. Aside from the problems of change over time, differences among ryâha, and the lack of detail in notation, there is also a certain amount of doubt as to whether the mainstream version of Midare was actually composed by Yatsuhashi Kengyô (ca. 1614-85). 
honkyoku - the group of pieces central to the traditional shakuhachi repertoire Icch $\hat{u}$-bushi - a genre of theatrical music for shamisen and voice iemoto - "head of the household," i.e. of the school

iemoto-seido-iemoto system; general term referring to the social organization of transmission and performance around an iemoto and her students; used for the Tea Ceremony and Flower Arranging as well as for music

Ikuta-ry $\hat{u}$ - one of the two main "schools" into which traditional koto music is now divided

jiuta - non-theatrical genre of music for shamisen and voice

jiuta-shamisen - the shamisen used in jiuta; also the music

jiuta-sôkyoku-jiuta pieces with added koto parts; also used as a collective term for koto music (sôkyoku) and jiuta, which are often played by the same people.

Kengyô - highest of the four main ranks in the tôdô-za

koto - 13-string zither-type instrument

kumiuta (koto kumiuta) - sectional vocal pieces accompanied by koto

kyoku - "piece"

nagauta - "long songs;" genre of music for shamisen and voice; used in Kabuki theatre

Nôkan - the flute used in the Nô theatre

ry $\hat{u}$ - "stream, school, style;" when used as a suffix, can be translated as "school" (e.g. Ikuta-ryûu)

ryûha - "schools and sub-schools;" from ryû and $h a$ ("faction, sect")

sakuhin - "work"

shakuhachi - end-blown bamboo flute 
shamisen - three-string lute-type instrument

sôkyoku - koto music

tôdô-za-the professional guild for blind men; originally for biwa players; in the Edo period, occupations included teaching koto music and jiuta, acupuncture, massage and moxa (see note 45 )

tsukemono - "attached things" (i.e. "attached pieces"); additional pieces attached to the main repertoire of koto kumiuta, for purposes of qualification and transmission in the tôdô-za

tsume - literally "nails;" plectra worn on the fingers and used for striking the strings of the koto

uchi-deshi - a live-in student (from uchi = "house," deshi = "student/disciple")

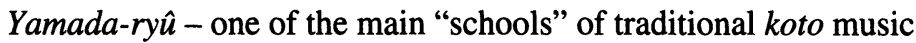

Yatsuhashi Kengyô (ca. 1614-85) - said to be founder of "traditional" koto music

\begin{abstract}
This paper examines traditionally-oriented teaching and learning processes in Japanese koto music. Earlier evaluations (negative and positive) by Western scholars are introduced, together with a brief comparison to Western practices. A distinction is made between "inside" and "outside" students; the former have greater exposure to music and speech about music, and teaching methods also may differ. Traditional methods of learning through imitation are shown to have other musical goals besides the transmission of musical "text." Playing together is fundamental; teachers may use speech, shôga (oral representation of instrumental sound), or purely musical means to convey information to the student. Notation, often used nowadays, is nevertheless of relatively minor importance. The dominant values underlying traditional teaching methods are expressed through the phrase "if you can steal it, that's OK." Finally, concepts of "text" and "interpretation" are considered in relation to values concerning change in traditional koto music.
\end{abstract}

